DOI: $10.14451 / 2.130 .7$

\title{
РОЛЬ УЧАСТНИКА ВЫБОРОВ В ИЗБИРАТЕЛЬНОМ ПРОЦЕССЕ
}

\author{
(c) 2019 Гадзиева Кристина Александровна \\ Самарский государственный экономический университет, Россия, Самара \\ E-mail: Gadzieva.k@mail.ru
}

Статья посвящена некоторым характерным чертам политической личности участника выборов. В работе определяется роль и политический портрет участника избирательного процесса как одной из основополагающих фигур в избирательном процессе Российской Федерации. Рассмотрены основные положения, касающиеся свободы слова, а также ее ограничения при проведении предвыборной кампании и выборов. Сделан акцент не только на политико-правовом портрете участника выборов, но и проведен необходимый анализ особенностей личностных качеств, которыми в идеале должен обладать каждый участник предвыборной гонки. Определена возрастная граница при проведении выборов, проанализирована проблема о необходимости наличия высшего образования у участника предвыборной гонки, выделены функции участника выборов, выделено итоговое понятие профессионального участника предвыборной кампании перед обществом.

Ключевые слова: выборы, предвыборная кампания, избирательный процесс, голосование, модель поведения, участник выборов, делегирование полномочий.

Участник предвыборной гонки - центральная фигура в предвыборной кампании, это своеобразное ядро, вокруг которого происходят основные действия, связанные с избирательным процессом.

П. Мерло отмечает: «Выборы - это часть, и важнейшая, политического по своей сути процесса и должны рассматриваться в общем контексте того, как в стране уважают и защищают гражданские и политические права» [1].

Очень верное утверждение, ведь выборы в конечном итоге направлены на делегирование полномочий в той или иной сфере лицу, которое сможет достойно представлять и защищать права и интересы граждан, будь то выборы президента или выборы в Государственную думу.

Участники избирательной кампании - граждане, предполагаемые к избранию либо назначению в органы государственной власти или органы местного самоуправления.

Право быть избранным - это, как широко известно, пассивное избирательное право. Оно предоставлено всем гражданам государства, проходящим под специальные цензы. К примеру, возрастной ценз кандидата в президенты РФ - граница в 35 лет.

Несомненно, дискуссии о роли и сущности участника выборов - один из наиболее сложных и коллизионных вопросов в избирательном процессе.

Итак, важно отметить, что функции участ- ника предвыборной гонки можно охарактеризовать следующими, преимущественно, тремя основными положениями [2]:

1. От воли участника избирательного процесса непосредственно зависят его функции в выборной гонке.

2. Участник выборов являет собой основные возможности объективного совершения действий не от своего имени, а от имени представляемого лица.

3. Функции участника выборов исходят от прав, которыми наделены избиратели.

Интересно указать, что как раз основная функция участника избирательного процесса, состоит в том, чтобы делегировать ему полномочия для представления непосредственно своих интересов избирателями.

Так какова же роль участника предвыборной кампании в избирательном процессе? Действительно, роль участника выборов в избирательном процессе нивелировать не представляется возможным.

Можно попытаться сделать умозаключение о том, что деятельность участника выборов по своей сути сравнима с деятельностью адвоката или судебного представителя, подобно тому как адвокат защищает интересы своего доверителя, так и участник выборов по своей сути защищает и отстаивает интересы граждан, лицом которых он является.

Также необходимо указать на тот факт, что 
участниками предвыборной кампании объективно являются дееспособные лица, которые имеют должным образом оформленные полномочия на ведение дела.

Но существуют также исключения из этого правила [3]:

- прокуроры,

- следователи,

- судьи.

При этом у них есть возможность принимать участие визбирательном процессе в роли представителей определенных органов или законных представителей [4].

Кроме того, надо отдать должное институту представительства, так как данный институт является одной из важнейших возможностей, которые применяется в сфере не только процессуальных, но и материальных правоотношений.

Так, для получения возможности участвовать в предвыборной кампании лицо должно отвечать высоким профессиональным и нравственным требованиям [5]:

- иметь безупречную репутацию,

- иметь высшее образование,

- опыт работы,

- основательно знать законодательство,

- обладать определенным набором нравственных и моральных качеств.

Ключевой проблемой в научной литературе и с практической точки зрения выступает то, что эти лица могут:

- быть недостойными с моральной точки зрения (например, иметь судимость);

- не обладать навыками ораторского искусства;

- не иметь образования;

- не иметь опыта и практики применения имеющихся знаний.

Но объективно, разве участвовать в выборах может лицо, имеющее исключительно высшее образование?

Поэтому вопросу мнения разделяются.

Необходимо отметить, что грамотное соблюдение требований к участникам предвыборной кампании, в том числе, имеет непосредственно важное значение для практики избирательного процесса.

Тем более что несоблюдение подобных требований приводит к привлечению к ответственности в указанной области. Данный вопрос будет рассмотрен ниже.

В настоящий период времени важное зна- чение приобретает контроль за деятельностью участников предвыборных гонок. Это очень важно для точного соблюдения прав и свобод граждан.

Важно отметить, что в настоящее время особенно остро существует необходимость в повышении требований к эффективности деятельности представителей интересов народа в целом [6].

Поэтому, на наш взгляд, наличие высшего, в том числе и юридического образования еще не является гарантией того, что лицо, желающее представлять интересы граждан, будет грамотным, подкованным в самых разных отраслях [7].

Кроме того, по нашему мнению, не следует уравнивать между собой наличие судимости и моральную неполноценность, к тому же если речь идет о судимости за неосторожные преступления. Тем более что отсутствие судимости не является гарантией моральной чистоты лица.

Какие бы были необходимы новшества в регламентации деятельности участников выборов для повышения эффективности и уровня качества их деятельности:

- активное включение участников в социальные сферы жизни общества;

- возможное возрастание роли выборов и, как следствие, повышение квалификации участников предвыборной гонки;

- восстановление справедливости относительно возлагаемых на кандидатов ограничений;

- государство получит право контролировать деятельность кандидатов на выборы, следовательно, независимость как сущностное свойство природы данного института гражданского общества нивелируется [8];

- естественная тенденция объединения юристов вокруг предвыборной кампании;

- критерий квалификации - образование и опыт;

- ликвидация различных правозащитных организаций;

- лишение граждан права выбора субъекта предоставления юридической помощи;

- налоговые поступления в бюджет.

Аргументы «против»:

- нарушение конституционного права на свободное использование своих способностей для не запрещенной законом экономической деятельности;

- необходимость ужесточить отбор канди- 
датов, ввести переэкзаменовку, более суровые меры взыскания.

- неуправляемый поток неквалифицированных кадров;

- опасения по поводу конкуренции в лице коллег, внедряющихся в сообщество по упрощенной схеме;

- отсутствие единых стандартов;

- отсутствие правового регулирования деятельности участников предвыборной кампании и квалификационных требований к ним;

- подрыв традиционных профессиональных и нравственных устоев в сложившейся системе выборов;

- пресечение недобросовестной конкуренции;

- система юридического образования, не соответствующая высоким задачам квалифицированной правовой защиты граждан;

- узкая и порой недостаточная квалификация;

Но, как показал опыт прохождения практики, существуют некоторые коллизии в законодательстве, которые связаны с вопросами участников предвыборной кампании, как представителей. Данные вопросы требуют теоретических и практических решений [9].

Таким образом, участник предвыборной кампании должен:
- представлять и защищать честь и достоинство всего общества в целом;

- в точности понимать объективные правовые и моральные ценности в связи с каждым гражданином и всем обществом,

- не пренебрегать правилами морали и этики.

Функции участника выборов тесно связаны с такой особенно важной правовой категорией как права человека. Тем самым, роль участника предвыборной кампании определяется степенью общественного доверия [10].

Таким образом, мы можем выделить следующее понятие профессионального участника предвыборной кампании перед обществом это система моральных и правовых обязательств перед гражданами, которые направлены на обеспечение реализации деятельности выборного представителя в интересах граждан с непосредственным соблюдением требований не только права, но и нравственно-этических норм.

Участник предвыборной кампании - это будущий общественный деятель, который в своем лице будет представлять интересы всего государства и каждого конкретного гражданина. Это трудная и ответственна работа, требующая сосредоточения всех сил, для достижения благополучия общества.

\section{Библиографический список}

1. П. Мерло Избирательный кампании и проблемы их подготовки: «Равное игровое поле» и демократические выборы // URL: http://www.civisbook.ru/files/File/1995_4_Merlo2.pdf.

2. Обухова Т.Л., Кирпичев Р.М. Проблемы положения представителей в судебном процессе // В сборнике: Ученые записки Нижегородский институт управления - филиал федерального государственного бюджетного образовательного учреждения высшего образования «Российская академия народного хозяйства и государственной службы при Президенте Российской Федерации». Нижний Новгород, 2015. С. 211-215.

3. Бойцова И.С., Туганов Ю.Н., Чуленков А.Л. Анализ судебной практики по взысканию судебных расходов по делам о защите прав потребителей с участием представителей // Вестник Екатерининского института. 2015. № 1 (29). C. 55-58.

4. Малиненко Э.В. Проблемы социальной политики в Конституциях и Уставах субъектов Российской Федерации как источниках конституционного права // Труд и социальные отношения. 2018. № 4. С. 45.

5. Куняев Н.Н., Чернявский А.Е. Правовые основы ограничения права граждан на получение и распространение информации в демократическом государстве // Образование и право. 2018. № 5. С. 36.

6. Закомолдин А.В. О проекте федерального закона «Об оказании квалифицированной юридической помощи в Российской Федерации» // Вестник Самарской гуманитарной академии. Серия «Право». 2009. № 2 (6). С. 100.

7. Корсаненкова Ю.Б. Роль экономической функции права социального обеспечения в преодолении социальных рисков // В сборнике: Современные риски и право: правовые средства предупреждения, управления, защиты. Сборник статей. Сер. «Муромцевские чтения » 2018. С. 169-175. 
8. Паращук С.А., Николаев К.А. Обзор работы научно-практической конференции на тему «Конституционные основы антимонопольного регулирования и их реализация в нормах конкурентного права России» в рамках VIII Московской юридической недели «Конституция Российской Федерации и современный правопорядок» // Приложение к журналу Предпринимательское право. 2019. № 1.

9. Афанасьев Е.Д. Понятие риска в частном праве // В сборнике: Юридическая наука и практика на рубеже эпох: уроки прошлого, взгляд в будущее (к 135-летию со дня рождения профессора Юрия Петровича Новицкого) сборник трудов XIV Всероссийских декабрьских юридических чтений в Костроме: Всероссийская научно-практическая конференция. 2018. С. 271-275.

10. Мухутдинов С.С. Место риска и права при рассмотрении судами уголовных дел политической направленности // В сборнике: Право и этика в глобальном обществе риска Материалы. 2016. С. 183-187. 